\title{
SOVEREIGNTY, STATE PARTICIPATION AND THE NEED TO RESTRUCTURE THE EXISTING PETROLEUM CONCESSION REGIME*
}

\author{
DR. HASAN S. ZAKARIYA**
}

\begin{abstract}
Serious discontent amongst oil exporting countries with the existing regime of petroleum concessions, particularly in regard to tax rates and levels of posted prices, has resulted in confrontations with corcession-holding countries, and much reassessment of the situation. Iraqi lawyer and diplomat, Dr. Zakariya calls on his experience with the Organization of Petroleum Exporting Countries (O.P.E.C.) to discuss some problems inherent in the scheme as it now stands. He looks especially to the issue of state participation and discusses several alter. natives such as curtailment of duration or the exercise of the legal right of nationalization open to those countries whose commitment to the existing system will not expire for many years. Dr. Zakariya considers the aims of such state participation, as well as the implications and legality of it, concluding in the hope that, with continued united efforts on the part of exporting countries, an amicable level of state participation will be soon realized.
\end{abstract}

\section{INTRODUCTION}

The tenability of the conventional regime of petroleum concessions has for some time been seriously questioned. This regime, as it exists in most of the countries now grouped in O.P.E.C. (hereinafter referred to as "the exporting countries") has, in fact, become so much of an anomaly that the exporting countries have felt compelled to intensify their efforts to have it revised, if not completely discarded. It is unnecessary to discuss the various inequitable aspects of this regime because for at least the last three decades these aspects have been widely discussed and publicized.

It is in this connection that state participation in both the ownership and the management and control of these concessions has been a matter of particular urgency for some time. Following the successful outcome early in 1971 of the negotiations in Teheran and Tripoli with the concession-holding companies (hereinafter referred to as "concessionaires") concerning the rate of income tax and the level of posted priceswhereby the respective agreements are to be in force for five yearsexporting countries were at once faced with the classic question: "Where do we go from here?" One might well have expected that at least some of these countries would have been tempted to call a moratorium on further claims, secure in the knowledge that in financial terms a favorable readjustment had just been accorded to them. Fortunately this has not been the case. The exporting countries appear, quite rightly, to be intent not only upon consolidating what they have recently gained, but also upon achieving positive results in other areas. In the absence of a unified stand on more radical action, no issue can rival the priority of state participation at the present time.

It was clearly inevitable that profound discontent with a situation so obviously inequitable should lead to several successive confrontations between the exporting countries and the concessionaires. To cite only a

- The text of a paper delivered by Dr. Zakariya at the symposium on "Petroleum Law and the Sovereignty of the Producing Countries" held in Algiers in October, 1971, formed the basis for this article.

- Iraqi lawyer and diplomat, formerly Chief of the Legal Department of the Organization of Petroleum Exporting Countries (O.P.E.C.). 
few examples, there was the nationalization of the Iranian concession in 1951; the promulgation of Law No. 80 in Iraq in 1961 which influenced the introduction of more substantial relinquishment of acreage in the Middle East; and the creation of O.P.E.C. which has proved to be a most useful instrument in safeguarding the collective interests of the exporting countries, culminating in the most recent confrontation concerning the tax rate and level of posted prices.

\section{The Implications of the Recent Confrontation}

Some of the implications of the latest confrontation can be assessed as follows:

1. Quite apart from the substantial gains now accruing to the exporting countries with regard to the rate of income tax and the level of posted prices negotiated recently, it is no less important to note a certain change of attitude on the part of the concessionaires. Whereas in the past the concessionaires regarded the fixing of the level of posted prices as solely their own prerogative, to be exercised without consultation with the exporting countries, they have now formally recognized for the first time that the exporters should have at least an equal voice in determining the level of posted prices. This has gone a long way in giving effect to one of the principles embodied in the O.P.E.C. Declaratory Statement of Policy of 1968 which stipulates that posted prices shall be determined by the exporting countries. ${ }^{1}$

2. It is to be recalled that this same principle also provides that in determining posted prices every endeavour should be made to prevent any deterioration in their relationship to the price of manufactured goods traded internationally. This idea also seems to have been at least partially recognized for the first time by the concessionaires in their acceptance of an annual increase in posted prices until 1975 , to counterbalance somewhat the effects of inflation.

3 . While in the past the concessionaires always refused to negotiate directly with O.P.E.C. as a collective entity, this confrontation has compelled them to reverse their attitude in this respect also. Not only have they agreed to negotiate with O.P.E.C. en bloc but, even more significantly, they have accepted O.P.E.C. Resolutions as a basis for negotiation. ${ }^{2}$

4. The concessionaires have again admitted by their own conduct that the doctrine of changed circumstances constitutes a valid basis for the revision of contractual terms.

5. Last, but not least, these negotiations have once more proved the effectiveness of solidarity and concerted action on the part of the exporting countries. This will no doubt prove to be an essential factor when the question of state participation is brought to the negotiating table.

1 The Statement of principle contained therein is as follows:

"All contracts shall require that the assessment of the operator's income, and its taxes or any other payments to the State, be based on a posted or tax reference pnce for the hydrocarbons produced under the contract. Such price shall be determined by the Government and shall move in such a manner as to prevent any deterioration in its relationship to the prices of manufactured goods traded internationally. However, such price shall be consistent, subject to differences in gravity, quality and geographic location, with the levels of posted or tax reference prices generally prevailing for hydrocarbons in other O.P.E.C. Counties and accepted by them as a basis for tax payments." (Emphasis supplied)

2 See eg. paras 2, 3-b, 3-c2 and 3-c2 (iii) of the Agreement concluded on February 14, 1971, in Teheran between the Guif States and the companies, in which O.P.E.C. Resolutions XXI, 120, 122 and 131 were explicitly cited. 


\section{Three Alternatives for Changing the Concession Regime}

Despite the improvements which have resulted from the various successive confrontations between the exporting countries and the concessionaires, the conventional concession regime seems to be in large measure still intact. The general position of the concessionaires has been maintained; their excessive profits, far from diminishing as a result of what they were recently forced to accede to the exporting countries, are likely to increase. ${ }^{3}$

By admitting Nigeria to full membership last July, O.P.E.C. can now claim to embrace most of the main net exporting countries in the world. Of these eleven countries, Indonesia abolished the concession regime in 1960 and replaced it by "production sharing" which is the only type of petroleum agreement permitted now in that country. As a result of the various state measures adopted during the last few years, the concession regime has also come to an end in Algeria. In all other nine O.P.E.C. countries the traditional regime still exists in varying degrees and covers by far the largest and most prolific fields being exploited there.

There is however a considerable difference in the expiry dates of concessions from one country to another. In the case of Venezuela, for example, it is as early as 1983 , while in Kuwait it is as far off as the year 2026. Venezuela has already promulgated comprehensive legislation designed to ensure, well in advance, an orderly, effective and complete state take-over upon the expiry of the present concessions just over ten years from now. ${ }^{4}$ One cannot but appreciate the way in which Venezuela-which has been one of the pace-setters among O.P.E.C. countries over the past three decades-has tackled this vital question. Thus one can understand why a country like Venezuela should not be keenly interested at this late juncture in state participation, or in the restructuring of its petroleum concessions.

The other exporting countries where the concession regime is still in force and is destined to be so for some years to come, if it is to be allowed to run its full course, cannot afford to wait until that eventual date of expiry-in some cases as much as half a century from now. Three possible courses of action lie open to them:

1. The curtailment of the duration of the concessions with a view to making the expiry date much earlier than originally stipulated. This could be achieved either by agreement with the companies, an eventuality which would seem to be highly doubtful, or as the result of legislative amendment adopted unilaterally by the state.

The Financial Times of London, July 10,1971, commenting on the recent agreements with regard to the level of prices and income tax, had this to say:

Essentially financial in nature, they have given the countries a massive increase in revenue after a decade in which this was the main bargaining point between the two sides. In structural terms, they have been more conservative. The position of the integrated oil companies as the producers, transporters, refiners and marketers of oil has been virtually untouched and may, indeed, have been strengthened. (Emphaiss supplied)

As to the expected rise in companies' profits, the Economist of London, February 20, 1971, observed: "It is actually possible that in the next two or three years, at any rate, the companies will be able $t o$ increase their return on capital."

At a later date, the Financial Times of London, June 11, 1971, reported:

During 1971, with margins recovering and sales growing, oil profits should reflect the long-term rising trend,'Sir David Barran, Chairman of Shell Transport and Trading, told the annual meeting of the company yesterday. Despite the considerable increase in taxes and royalties which had been conceded to the producing countries, he stated, it had been possible "to recover in prices in most countries not only these increases in costs but also something of the erosion of margins that had occurred during 1969 and 1970".

- Oil Reversion Law, signed on July 30, 1971. One of the main and bold features of this important law is the creation of a "Guarantee Fund" by the concessionaires, to be kept by the Venezuelan Government as a "col. lateral" to ensure their strict compliance with the law. 
2. The exercise of the legal right of nationalization, with the possibility of later entering into new and more equitable arrangements in keeping with present realities, either with the present concessionaires or with newcomers. At this particular time the feasibility of such a measure would still seem to be somewhat problematic and it is not yet clear if a unified and determined stand can be taken on this issue by all the exporting countries for the present. Naturally the matter will have to be studied most closely as to all its ramifications, and all its possible consequences must be taken fully into account.

3. Short of complete nationalization-and perhaps even as a useful, practical prelude to it-the third alternative is the immediate restructuring of the existing concessions by means of the state or one of its agencies becoming a new partner or shareholder in the enterprise. This is the subject upon which this paper will dwell as it appears to be the general direction in which the exporting countries are actually moving.

\section{BRIEF SURVEY OF STATE PARTICIPATION UNDER THE EXISTING CONCESSIONS}

For the purpose of the present discussion it is both necessary and useful to enquire whether state participation exists under the present concession regime and, if so, in what form and to what extent.

\section{Participation in the Equity Ownership}

1. Old Concessions-Under the conventional concession regime, the idea of state participation hardly existed. Two instances could be cited here in which the state, under certain conditions, was entitled to acquire a certain percentage of the equity ownership. While they had very little practical value, their moral significance was nevertheless considerable, since they demonstrated that at least half a century ago, the companies basically accepted the idea of state participation even at a time when they and their respective governments were at the height of their negotiating, or rather dictating, power. It is paradoxical that instead of allowing this idea to develop, the companies have chosen instead either to eliminate it subsequently or to prevent, quite deliberately, its realization.

The first of these instances is the D'Arcy Concession of 1901 which provided that the Government of Iran would receive fully paid up shares in the operating company to the value of 20,000 pounds sterling within a month after its incorporation. This represented one-thirtieth of the equity of the company of which the capital was quoted as 600,000 pounds sterling. However, about thirty years later, the Anglo-Persian Oil Company Concession of 1933, which replaced the D'Arcy Concession, did not provide for an initial state participation in the equity ownership of the concession. Instead it made a stipulation in Article 18, similar to that of the I.P.C. Agreement (which will be discussed next), to the effect that the concessionaires should make shares, which might be issued in the future, available for subscription in Teheran simultaneously with those offered abroad. As expected, this optional clause remained a dead letter throughout the life of the A.P.O.C. Agreement which was terminated by the Nationalization Act of 1951.

The second instance is the I.P.C. Agreement in Iraq which attempted to reflect the terms of the San Remo Treaty of 1920 signed by Britain and France and provided, in Article 34, for the following: 
Whenever an issue of shares is offered by the Company to the general public, subscription lists shall be opened in Iraq simultaneously with lists opened elsewhere, and Iraqis in Iraq shall be given a preference to the extent of at least 20 percent of such an issue.

The inherent weakness in the drafting of this article is quite obvious. The Iraqi participation was made conditional on the future issue of shares which would usually mean the increase of the company's capital. Since such a step could only be taken by I.P.C. itself, what was needed to suspend or evade the implementation of this article and to deny any Iraqi participation in I.P.C. was simply to refrain from issuing any shares. It is to be recalled that the perennial I.P.C. answer to the repeated demands by the Iraqi Government that this provision should be carried out in good faith, was as unabashed as this: "Since we are not a public company, we simply do not and cannot issue shares to the public." The sinister irony of this situation needs no further comment.

2. More Recent Concessions-Although some of the concessions granted during the last quarter of a century do not differ in essence from the old and conventional ones, they nevertheless introduced the idea of state participation in a less meagre form. This has the added significance of strengthening, at least indirectly, the case for participation on the basis of changed circumstances, a major argument which the exporting countries are now advancing.

In this connection, one can cite the Aminoil Agreement of 1948 with Kuwait covering her share in the Neutral Zone. The concession provided in Article 3-f for state participation to the extent of fifteen percent of the shares without payment. In more recent years the option to participate in the equity ownership of the concessionary company has not been made dependent upon the offer of new shares, which lies obviously within the sole discretion of the concessionaire, but has rather been made conditional only upon the discovery of oil.

Thus the Japanese Petroleum Trading Company Agreement of 1957 provides that after the discovery of oil in commercial quantities, the concessionary company should undertake to offer for subscription to the government shares representing ten percent of its paid up capital. Such an option would apply also to any subsequent offer of shares. The Kuwait/Shell Agreement of 1961 similarly provides for the participation of the Kuwait Government in up to twenty percent of the equity of the concession company within ninety days of the discovery of petroleum in commercial quantities.

\section{Participation in the Management}

The exporting countries have not only been unduly prevented from obtaining a meaningful share in the equity ownership in the majority of the conventional concessions, as has been shown, but partly as a result of this, have also been denied any effective participation in the actual management and control of the various operations of the concession. Modest attempts were made in some of the early agreements to establish a certain contact between the government and the management of the concessionary companies. This was the case in both D'Arcy and the A.I.O.C. Concessions of 1901 and 1933 respectively in Iran, as well as in the I.P.C. Concession of 1925 in Iraq. The governments of Iran and Iraq were given, with minor variations, the right to appoint a "commissioner", a "representative" and a "director" to attend the board meetings of these companies. 
In more recent years, however, it has become almost a generally accepted practice in the exporting countries to nominate one or two representatives to the board of directors. There is no need to review here all the various provisions existing in this regard. It is safe to point out, however, that such government representation on the boards of the concessionary companies is merely symbolic and has had in practice little or no influence on the policy decisions.

\section{STATE PARTICIPATION AND O.P.E.C.}

Prior to the creation of O.P.E.C., state participation had been one of the outstanding issues of contention between Iraq and I.P.C., in view of the fact that Article 34 of the 1925 Agreement had, as already noted, never been implemented.

In more recent years, state participation has gained increasing attention outside Iraq, particularly in those countries such as Saudi Arabia and Kuwait where the concessions did not provide for any initial or eventual participation. The first formal recognition of participation as one of the main objectives of O.P.E.C. countries is contained in the well-known Resolution XVI.90, passed in June, 1968, which embodies the Declaratory Statement of Petroleum Policy, the second principle of which reads as follows:

\footnotetext{
Where provision for Governmental participation in the ownership of the concession-holding company under any of the present petroleum contracts has not been made, the Government may acquire a reasonable participation, on the grounds of the principle of changing circumstances. If such provision has actually been made but avoided by the operators concerned, the rate provided for shall serve as a minimum basis for the participation to be acquired.
}

It is to be recalled that O.P.E.C. has not been content merely to declare its desire to implement this idea somehow, some day. It has been pursuing the particular issue ever since.

State participation has been on the agenda of most O.P.E.C. conferences since June 1969. During this time several thoughtful studies were conducted within the Organization, dealing with the issue from its various legal, economic and technical aspects and with the best means of implementing it. The issue was again taken up in December, 1970, at the Twenty-first Conference which established a Ministerial Committee to study this matter and to report its findings to the next conference. During the Twenty-fourth Conference held in July, 1971, Resolution XXIV.135 was adopted which, after indicating that changed circumstances imply the right of O.P.E.C. countries to participate in the existing oil concessions, stated that these countries should take immediate steps towards its effective implementation. Another Ministerial Committee of five was formed to draw up a basis for putting this into effect and to submit its recommendations to an extraordinary conference which was convened in September, 1971, in Beirut. The result of this conference was the adoption and ratification by all member governments of a number of Resolutions, one of which was Resolution XXV.139 stating that:

(i) all governments concerned are to start negotiations with the oil companies either individually or collectively in order to achieve participation on the bases proposed by the Ministerial Committee set up by the previous Conference; and that

(ii) the results of the negotiations are to be submitted to the next conference to be held in Abu Dhabi ... . for co-ordination. 
Since the bases proposed by the Ministerial Committee alluded to above have not yet been officially disclosed, the trend of thought within O.P.E.C. on such important matters as the percentage of participation to be sought, the petroleum activities to be covered and the basis for compensation to be paid for the participation share to be acquired, are still not authoritatively known and are, therefore, bound to become the subject of speculation. However, the reaction of the press and oil companies alike to Resolution XXV.139 seems, so far, to have been relatively mild and subdued. The following quotation might illustrate the general attitude: ${ }^{5}$

\begin{abstract}
On participation the demands were more conservative than had been feared by many people in the industry... Oil companies could find consolation in two senses from yesterday's statement (i.e. publication of Resolution XXV.139). First, the oil producing countries are not presenting a united cartel as they did with their last demands for increased revenues and secondly they are not committing themselves to radical demands as had once been feared....
\end{abstract}

\title{
IV. OBJECTIVES OF STATE PARTICIPATION
}

It would perhaps seem superfluous or merely academic to discuss the desirability of state participation or to enquire into the objectives it is supposed to accomplish. Nevertheless, no matter how obvious these objectives might appear, it is essential to allude to them at least in brief since they are of paramount relevance not only in determining the percentage of participation which should be sought (a particularly crucial question), but also in selecting the most effective method of implementation.

It is, of course, at once clear that ownership participation in the concessions would certainly increase the state's share of profits. By becoming a partner in a very lucrative enterprise, the state would naturally be entitled to receive-in addition to royalties, taxes and the other benefits which are already accruing to it-a share of the annual dividends in accordance with normal business practice. Although such an increase in the revenues is of itself sufficient reason for desiring state participation, there are other intangible advantages to be derived from it in the long term. As a second best alternative to direct exploitation of petroleum resources, which should, of course, always be the ultimate aim, participation is designed to achieve, although in an incomplete form, the same important aims as direct exploitation is supposed to accomplish. These aims are not hard to ascertain. They are mentioned, for example, in the preamble to the O.P.E.C. Declaratory Statement of Policy of 1968 (paras. A. B. and D) which echoes the spirit and letter of the U.N. Resolution on Permanent Sovereignty over Natural Resources and, more particularly, of the U.N. Resolution of 28 November, 1966.

By enabling their experts to play an active and direct role in the various day-to-day aspects of petroleum operations, the exporting countries concerned would acquire first-hand experience in these matters which would prove invaluable in facilitating the task of eventually taking over these operations completely, upon the expiry of the concession or perhaps even before that date. Moreover, by taking an effective part in the actual management of the whole enterprise, which participation would entitle it to do, the country concerned would at least enjoy 
the same privileges as the foreign concessionaire in directing the way in which petroleum resources are to be utilized and in shaping the policies to be pursued in both the short and long term.

All these are vital aims which transcend the mere raising of government revenues. The legal measures taken to attain these aims should of course be of such a nature as to guarantee their realization in the shortest possible period of time. This would inevitably lead to the crucial question discussed next.

\section{THE EXTENT OF PARTICIPATION TO BE ACQUIRED}

The principle on participation in the O.P.E.C. Declaratory Statement of 1968 stipulates the acquisition of a "reasonable participation" if participation was not provided for in the initial agreement. In cases where such a provision was made then the rate provided for would serve as the minimum basis for the percentage of participation to be acquired. This latter contingency refers clearly to the unique case of Iraq where the I.P.C. concession provides for a rate of twenty percent. The Twenty-fifth Conference, however, adopted this percentage as the minimum to be sought initially on the understanding that it would later be increased. But it has been reported that each O.P.E.C. country will be left free to make its own demands and that it is believed that Libya will demand a fifty-one percent share while the six Gulf States of Abu Dhabi, Iran, Iraq, Kuwait, Qatar and Saudi Arabia are expected to ask for twenty percent, and Nigeria is likely to seek thirty-three percent participation. ${ }^{6}$

As to the compensation for the participation share to be acquired, it is reported that O.P.E.C. is understood to have agreed to use the net book value of investments as a yard-stick for payment to the concessionaires. ${ }^{7}$ It is interesting that this report goes on to point out that, according to varying estimates, the net book value of ARAMCO in Saudi Arabia and the Consortium in Iran might be around 500 million dollars each, while Kuwait Oil Company's book value might be 250 million dollars. In other countries, the net book values would be considerably less. Thus, twenty percent or more of these estimates would be, in the opinion of this report, "cheap" compared to the true costs of the multibillion cash-flow business involved.

If the sole aim of participation were simply to increase the government share in profits, then any percentage in the ownership of the concession would do, the greater the better, of course. However, if the objective is also along the lines already mentioned, then the extent of participation should be such as to secure for the government concerned representation on the management of the enterprise at least equal to that of the foreign concessionaire. Whether this equal representation should coincide with and reflect an equal division of shares between the government and the concessionaire might be a debatable matter which perhaps should be left in the first instance to the skill and tenacity of those who negotiate this issue on behalf of the O.P.E.C. countries, individually or collectively. It is, however, highly important that this basic target should at all times be borne in mind, since participation cannot achieve all its fundamental aims unless the state has at least an equal voice in the actual management of the enterprise.

- The Oil and Gas Journal, Tulsa, October 4, 1971 and The Times, London, October 8, 1971.

The Oil and Gas Journal, Tulsa, October 4, 1971. 
All this having been said, one feels that a satisfactory formula would enable the state to acquire at least fifty-one percent of the equity ownership which, in turn, would be reflected in the composition of the management. If in the circumstances this percentage of ownership proved too high to be feasible, then the country concerned should endeavour to secure equal representation in the management, irrespective of the rate of participation in the equity.

\section{PARTICIPATION IN WHAT?}

One of the most crucial questions which will inevitably arise in this context is to which of the various petroleum operations state participation should apply and whether or not it should also extend to those activities conducted by the concessionaires or their affiliates outside the territorial jurisdiction of the state, loosely called "downstream" operations. In its journey from the well-head to the nozzle in the service station, petroleum passes through four main stages-production, transportation, refining and marketing. Production is distinct from the other three inasmuch as it is always carried out exclusively within the territory of the exporting country. The other phases-transportation, refining and marketing-although sometimes conducted within the territorial limits of the exporting country are, as things stand now, predominately carried out beyond these territorial limits. Again, to gauge the complexity of the problem, some phases of the operations are conducted by the concessionaire party to the original contract; others are normally carried out by other corporate entities which are, more often than not, affiliated to the concessionaire in the notoriously intricate labyrinth of the world petroleum industry as we have come to know it.

Before taking any step towards its implementation, due consideration must be given to which of these four phases state participation should apply, at least in the short term. Actually, this question has not been overlooked in the course of discussions on participation during the last few years, both within O.P.E.C. and outside. It has also been debated at various levels and reported to some extent in the trade journals. ${ }^{8}$ If suffices to mention in passing that there were until recently two main schools of thought. One tended to advocate the restriction of state participation to the production stage together with all those ancillary activities carried out within the territorial jurisdiction of the state itself, i.e. "upstream" operations; the other contended that participation should at once apply to "upstream" and "downstream" operations, in the belief that only thus could the level of prices be maintained.9

It goes without saying that effective participation in and control over all the various phases of the petroleum industry should be the aim of the exporting countries. But, all things considered, could this be attained at present without any risks at all? The facts must be faced soberly. On close scrutiny, the idea of participation in "downstream" operations would seem at present to be an over-ambitious one, fraught

\footnotetext{
- See e.g., Supplement to Middle East Economic Survey, Vol. XII, No. 37, 1 \& 2 (July 11, 1969).

- The Oil and Gas Journal, Tulsa, August 2, 1971, quoted Mr. Ahmad Zaki Yamani, Saudi Arabian Minister of Oil and once a staunch advocate of "downstream" participation, as saying: "The oil market, which until the recent past was a buyer's market, has now become a seller's market . . . and this being the case our appetite for "downstream" operations is definitely diminishing."

It is to be noted that the main argument advanced by the exponents of "downstream" participation was that to confine participation to the "upstream" stage only, would result in a large increase in supply in world markets, with all the ensuing adverse effects on crude prices. This fear has not only proved recently to be exaggerated, but should be dispelled altogether in light of recent forecasts for the massive increase in future world demand for oil.
} 
with major legal and financial difficulties. But even assuming that these difficulties were surmountable, the time and effort required to overcome them would, for all practical purposes, preclude the possibility of achieving any state participation in the reasonably short time which the urgency of the issue requires. This probable delay might have the practical effect of shelving the idea of participation altogether, or at least indefinitely, and no one, not even the most ardent advocate of "downstream" participation would wish this to happen.

There are three main arguments against the feasibility of "downstream" participation which should be particularly emphasized here:

1. One of the most obvious relates to the "financial burden" which the exporting countries would have to bear if they were eventually able to participate in "down-stream" operations. It is now widely recognized that such participation would require enormous investment. With a few exceptions, the exporting countries do not at present have a ready surplus of capital to devote to such a costly venture. Even if they did, it would be at the expense of their national development programs which are so essential to the economic progress and social welfare of their people.

2. Even if the necessary funds were readily available to enable the exporting countries to buy their way into "downstream" operations, and even if it were both possible and advisable at this juncture for these countries to assume the role of capital exporters, an important factor must not be lost from sight: would it be a wise policy as things now stand, to acquire considerable assets abroad which could be held to ransom and become subject to possible retaliatory measures in the future? It is a fact that the process of economic emancipation has not been completely achieved in most of these countries and taht they might find themselves compelled sooner or later to take certain legal measures to expedite that process. So long as this is the case, clearly the exporting countries, should think more than once before unwittingly exposing themselves to any possible blackmail or inhibiting factor. The following is an interesting illustration of this: commenting on rumours (which subsequently proved to be unfounded) that Saudi Arabia was the first of the Arab oil producing countries to start talks with the Consortia now prospecting in the North Sea in the hope of joining in the hunt, the Economist of London on 3 July, 1971, stated: "If O.P.E.C. countries join the exploitation of the North Sea, the two-way benefits could be considerable: For one thing they might be less inclined in future to expropriate us if we could in turn expropriate them. ..." (emphasis supplied).

3. In contrast to participation in "upstream" operations, the options for implementation of "downstream" participation are very limited indeed. Most cuch operations are now conducted outside the boundaries of the exporting countries and are therefore beyond their sovereign jurisdiction. If such participation is sought it can come about only with the consent of the concessionaire and affiliates world wide. The possibility of the concessionaires readily acquiescing in this seems at this time to be remote. Even if, under extreme pressure, they did agree to the idea in principle, the very complexity of the problems involved would seen to rule out the possibility of arriving at a formula satisfactory to both parties, without long-protracted negotiations which might well end in deadlock. How- 
ever, the implementation of participation in "upstream" operations is not open to the same pitfalls, since in this case the exporting countries always have the ultimate option of exercising their sovereign right of nationalization, partial or complete.

The firm conclusion to be drawn from all this is that no matter how tempting "downstream" operations might appear, the exporting countries will have to confine their demands now, en bloc, to participation in production and all ancillary activities, carried out exclusively within the territorial jurisdiction of each country. Participation in "downstream" operations should be left to a later stage, or at least to each individual country to decide upon, with extreme caution, should it possess the necessary capital and after satisfying itself of the absence of any real risks.

Incidentally, it should be noted in passing that although the O.P.E.C. Declaratory Statement of Policy of 1968 is not very explicit on this point, it seems to envisage participation in "upstream" operations only. It is likely that only this form of participation would achieve unanimity and complete solidarity among all the exporting countries; it would also ensure that participation is implemented as promptly as the urgency of the matter demands. The O.P.E.C. Bulletin ${ }^{10}$ reported that the O.P.E.C. Secretary General stated on 13 October, 1971, in an interview with a group of six U.S. institutional investors, in reply to their remark that O.P.E.C. appeared to have diminished its desire for participation in "downstream" operations, that:

The O.P.E.C. Declaratory Statement dealt with the principle of participation in "upstream" operations only. At several stages we have considered the possibility of extending participation beyond national boundaries. However, it has been decided to concentrate our efforts on "upstream" operations only, and "downstream" participation can be studied at a later stage.

\section{THE LEGALITY OF PARTICIPATION}

Although equitable and long overdue, the call for state participation would predictably meet, initially at least, with strong objections from the concessionaires. As a matter of fact, this has already happened. A few months after the adoption of the O.P.E.C. Declaratory Statement of Policy of 1968, the President of a certain major company operating in the Middle East, went on record in a published letter objecting to the idea of participation and raising, as expected, the familiar banner of "sanctity of contracts". He denied that the doctrine of "changed circumstances" is a valid basis for the revision and modification of contractual terms which were initially, or have subsequently become, inequitable or harsh. ${ }^{11}$ The contentions of this major company executive, however, did not go unanswered. It is not necessary here to demonstrate the flaws in his contentions nor to prove the validity of the doctrine of "changed circumstances" as this has been done elsewhere. ${ }^{12}$

\footnotetext{
${ }^{10}$ No. 6 of 1871 .

1 Letter to the Editor, signed by Mr. R. Brougham, President of Pramco, enclsoing a legal opinion by Dr. Saba Habachy on "Participation and Change of Circumstances", published in the Supplement to the Middle East Economic Survey, Vol. XII, No. 8 (December 20, 1968).

12 "Impact of Changing Circumstances on the Revision of Petroleum Contracts", a paper delivered in Vienna by Dr. H. S. Zakariya on 3 July, 1969 at the O.P.E.C. seminar on "Internation Oil and the Energy Policies of the Producing and Consuming Countries". In addition to being included in the collection of papers pre sented at that seminar and subsequently published by O.P.E.C. this paper was also printed in the Middle East Economic Survey, Vol. XII, No. 37 (July 11, 1969), in Le Petrole et Le Gaz Arabes, Vol. 1, No. 8 (July 16, 1969), and in Arabic in Risalat al Bitrol al-Arabi, Vol. 2, Nos. 32 \& 33, 21 and 28 July, 1969 respectively.
} 
There are, of course, further important considerations in support of the call for state participation. It is clear that exhaustive treatment of this subject is beyond the limited scope of this article, but some of them will be referred to briefly.

The United Nations passed resolutions on "Permanent Sovereignty over Natural Resources", the first of which was adopted in 1952 and the last on 28 November, 1966. This last resolution placed great emphasis on, among other things, the right of all countries, more particularly the developing ones-a category to which all oil exporting countries belong - to secure and increase their share in the administration of enterprises which are fully or partly operated on their soil by foreign capital and to have a greater share in the benefits deriving from them on an equitable basis. Here in essence lies the true significance and main target of permanent sovereignty over natural resources, namely, the maximization of the benefits accruing to these developing countries from the exploitation of their natural resources. How, short of complete take-over, is it possible in practical terms to put this idea of maximization into effect without allowing the exporting countries at least to participate in the ownership and management of these concessions for their remaining duration? It is clear that this maximization could only be achieved either by outright take-over (nationalization) or gradually, by the accelerated acquisition by these countries of an increasing share in these operations. Furthermore, nationalization of private property is a widely accepted prerogative of all states, the exercise of which is subject only to payment of appropriate compensation to the affected private parties. This was conclusively reaffirmed by the United Nations with an overwhelming majority on 14 December, 1962.

It goes without saying that the failure to implement participation amicably would entitle the exporting countries to bring it about unilaterally by state action which would amount in fact to "partial nationalization". This partial nationalization is a fortiori just as valid and justifiable as complete nationalization.

Whether or not United Nations resolutions can be said to establish new norms of international law, may still be debatable. But this will never detract from the important fact that these resolutions, particularly those which were passed by an overwhelming majority such as that of 28 November, 1966, represent the consensus of opinion of the contemporary world community and, as such, should be regarded as a source of an emerging and progressively developing international law, or, at least of the body of the so-called "General Principles of Law" common to civilized legal systems which, incidentally, have frequently been invoked on behalf of the major petroleum companies.

\section{HOW TO IMPLEMENT STATE PARTICIPATION}

At present all the indications are that the exporting countries have decided to put state participation into effect soon. ${ }^{12}$ But before they do so they must, of course, collectively prepare the ground by drawing up a carefully worked out strategy to cover all possible contingencies before beginning the confrontation they will certainly have with the concessionaires. It is not intended here to discuss at length the mode of implementation, which is a vital and complex issue and which, in itself, would require another extensive and separate report. Nevertheless, a few thoughts of a general nature in this regard, might be in order. 
As has already been seen, state participation was written into the O.P.E.C. Declaratory Statement of Policy of 1968. The call for its immediate implementation was explicitly stated in O.P.E.C. Resolution XXIV.135, adopted in July, 1971. Both this statement and this resolution as well as those of the Twenty-fifth Conference have been duly ratified by all O.P.E.C. countries. But does this ratification make state participation mandatory within each of these countries? The answer is surely "no". It is still necessary for an internal legal measure, such as a legislature act or an executive decree to be adopted in each of them. This would stipulate clearly that within a specified period of time-to be as short as possible-all concessions still in force would be amended in such a way as to enable the state, through its proper agency, to become an active partner in all the petroleum operations carried out within its territorial jurisdiction. It would also prescribe the rate of participation to be acquired.

Such an internal legal measure would prove highly useful since it would demonstrate to all the firm resolve of the countries concerned to bring the concession regime in its present form to a speedy end, and to replace it with a more equitable substitute, in keeping with new trends and practices. It would also strengthen the position of the exporting countries, individually and collectively, in the forthcoming negotiations on this issue, by making state participation a fait accompli. The initial opposition of the other side to the idea would thus be considerably minimized and any procrastination or delaying tactics to which the companies might resort, as they have done in the past, would undoubtedly be curtailed.

Since the "national oil company" is the most appropriate vehicle for the implementation of state participation, it is clear that every exporting country seeking participation should set up such a company. With the recent announcement that Abu Dhabi is about to establish a national oil company, this requirement has been virtually fulfilled, since all the other O.P.E.C. countries now have their own national companies.

Without wishing to dwell at length on their various conditions and implications, one can point out that there are obviously two methods of implementing state participation: either amicably, that is with the consent of the concessionaires; or forcibly by unilateral action. There seem to be two alternatives for the amicable implementation of participation:

1. By amending the legal entity of the present concession in such a way as to enable the state to become a new shareholder in the enterprise, or preferably

2. By dissolving the present legal entity and replacing it with a new one such as a joint venture to be registered in the exporting country itself, the capital of which would be assigned to both the state and the present concessionaire in accordance with the rate of participation to be acquired. It is to be remembered that this was the course adopted in converting the Getty Concession in Algiers in October, 1968, into a joint venture company, fifty-one percent of its capital being allocated to Sonatrach and forty-nine percent to the Getty Petroleum Company.

In seeking to implement participation, the exporting countries would naturally be expected to attempt, in the first instance, to do so through negotiation with their respective concessionaires primarily for the sake 
of settling amicably the amount and mode of compensation. No one would deny that this course of action should be explored first.

However, should the concessionaire refuse to enter into negotations, or if he does agree to do so but the negotiations become deadlocked, the exporting countries would have to be prepared to implement participation unilaterally. This would no doubt take the shape of partial nationalization of the existing concession, somewhat along the lines followed recently in Algeria with regard to the French petroleum interests.

It is to be sincerely hoped that in implementing state participation in the days ahead, the exporting countries will demonstrate at least the same degree of concerted effort, solidarity and determination as they did during their last confrontation with the companies concerning the level of posted prices and rate of income tax. If so, their success on this even more crucial issue will be likewise assured. 